NBER WORKING PAPER SERIES

THE THEORY OF OPTIMUM DEFICITS AND DEBT

Willem H. Buiter

Working Paper No. 1232

NATIONAL BUREAU OF ECONOMIC RESEARCH

1050 Massachusetts Avenue

Cambridge, MA 02138

November 1983

The research reported here is part of the NBER's research program in International Studies. Any opinions expressed are those of the author and not those of the National Bureau of Economic Research. 
NBER Working Paper \#1232

November 1983

The Theory of Optimum Deficits and Debt

ABSTRACT

The paper surveys a number of neo-classical and neo-Keynesian approcaches to government financial policy. After reviewing the very restrictive conditions under which financial policy is just a veil without real consequences, non-neutral financial policy in neo-classical models is analyzed. At full employment, the substitution of borrowing for lump sum taxes crowds out private capital formation in a closed economy. Government financial policy can be used to implement optimal intertemporal risk distribution schemes. In the presence of distortionary taxes, the smoothing of tax rates over time may be optimal even where this involves systematic and predictable departures from continuous budget balance.

The case for deficit finance and the operation of the automatic fiscal stabilizers in a Keynesian world with disequilibrium in labour and output markets is restated.

The case for any kind of active financial policy rests on the presence of capital market imperfections (including incomplete contingent forward markets such as insurance markets), on the longevity of the institution of government and on the government's unique ability to tax.

Finally, certain long-run aspects of the fiscal and monetary stance are analyzed. This includes their sustainability, 1.e. the consistency of longterm spending and taxation plans with the monetary objectives and the crowding out targets. The concepts of the comprehensive net worth of the public sector and its permanent income are central to this analysis. The current U.K. position appears to be one of an unsustainable, "permanent surplus."

Willem H. Buiter

London School of Economics Houghton Street London WC2A $2 \mathrm{AE}$ England 01-405-7686 
1. Introduction

This paper deals with some of the issues that arise in connection with the optimal financing of a given programme of "exhaustive" public spending on goods and services. The determination of the size and composition of this real spending programme is not considered. A more general view would encompass the optimal joint determination of the public sector's consumption and investment programme and its method of financing, but even the less ambitious approach adopted here raises a very wide range of issues and considerations.

Government financial policy is about the management of the public sector balance sheet, broadly defined. It includes the choice of taxation versus borrowing. It also concerns the composition or structure of taxes (lump-sum, direct, indirect, degree of progression, etc.) and the characteristics of the debt instruments issued by the government (interest-bearing or non-interest bearing, legal tender, maturity, degree of indexing, etc.). Monetary policy, exchange rate management and foreign exchange market intervention therefore belong to financial policy as much as open market operations or bond issues "to finance the deficit". It should be obvious that questions concerning the distribution of income (intra-generational as well as intergenerational) are inextricably intertwined with questions relating to the financing of a given real spending programme. Stiglitz $(1983 a, b)$ has emphasised the inevitable intertemporal and intergenerational risk-sharing attributes of financial policy, something I shall return to in section II. 
Like any other kind of government intervention in the economy, government financial policy can be rationalised in one of two ways. The first is intervention for purely distributional reasons. While they are of major importance, I shall not pay much attention in what follows to the distributional objectives of the government. The disttributional consequences of alternative financing rules will, however, be central. Indeed financial policy influences real economic variables largely by affecting the intertemporal and interpersonal (including intergenerational) distribution of income and wealth. The second justification for financial policy is the identification of instance(s) of market failure together with the attribution to the government of the ability to undertake remedial welfare-improving actions that private agents either cannot undertake or do not find in their own perceived self-interest to undertake.

The market "imperfections" central to an appreciation of the potential welfare-improving role of financial policy are capital market imperfections. Included in this are any restrictions on the ability of private agents to effect intertemporal transfers of purchasing power in either direction at social intertemporal terms of trade. In the overlapping generations model with finite lives and without operative intergenerational gifts and bequests, the incompleteness of the set of forward markets (or the absence of a full set of Arrow-Debreu securities) is due to the "technological" constraint that the dead cannot consume goods and services and the legal constraint that private agents cannot impose binding financial obligations on the unborn. In real life this 
non-existence of certain forward markets is augmented by a wide array of capital market imperfections. Private agents are constrained in their spending plans by the illiquidity and non-marketability of certain assets such as pension rights and human capital (including expected future income tax cuts). Collateral requirements limit access to credit. These cash flow constraints, liquidity constraints, lack of suitable collateral, non-marketability of certain assets and a host of similar capital market imperfections need not take the form of strict credit rationing but may instead merely be reflected in a market price of credit that is in excess of its shadow price.

My. inability to borrow on the same terms as the U.K. government is of course not in and of itself evidence of market failure. Recent applications of the theory of market equilibrium under asymmetric information to credit markets (see e.g. Webb [1981], Stiglitz and Weiss [1981, 1983]) however, have shown how adverse selection or moral hazard can generate privately rational but socially inefficient equilibria that may be characterized by credit rationing, excessive spreads between lending and borrowing rates, etc.

Granted the existence of significant and persistent capital market imperfections, does the "opportunity set" of the government differ from and in certain respects dominate that of private agents? In the overlapping generations model already referred to, there are two features that differentiate private and public possibility sets. First, the institution of government is longer-lived than the individual 
private agents. Frequently endowed with eternal life, governments can, in these models, enter into contracts that extend beyond the life-span of any given generation. In this way governments can be a substitute for some of the non-existent forward markets. Second, the authorities have the power to tax, i.e. the power to impose unrequited charges or payments on individuals. For good reasons, governments are exceedingly jealous of this power and discourage private agents from assuming this prerogative which is classified as theft when exercised on private initiative.

The power to tax enables the government to redistribute income between members of the same generation at a point in time, over time for an (a group of) individual(s) and between generations. This power to $\operatorname{tax}$ is also the reason why, in an uncertain world, governments can borrow on terms that are superior to those faced by private agents. Total current and future national income is, subject to political constraints on the tax burden, the collateral for government borrowing. The risk of default through insolvency (but not of discretionary or dishonest default) is therefore less for governmentbonds than for private debt. Most governments also have the power to determine what shall be legal tender. Almost all have opted for a government monopoly of legal tender, thus adding directly to the attractiveness of those of their liabilities designated to be legal tender (their monetary liabilities)

1. Clearly I.B.M. borrows on better terms than the state of Grenada. The insertion of the word "most" before 'governments' and 'private agents' would, however, merely clutter up the text. 
and improving indirectly the quality of all public debt. Most of the other differences between private and public opportunity sets referred to in the literature derive from the greater longevity of the institut-

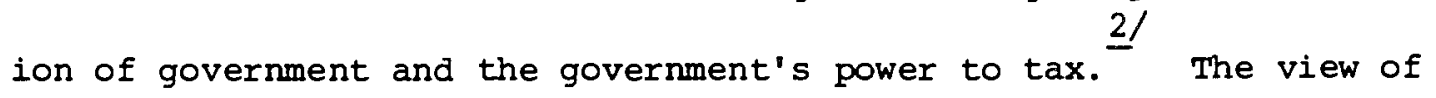
government financial policy I am advocating has governments acting as a superior financial intermediary, changing the composition of private sector portfolios over time and altering private disposable income flows. Well-designed policy interventions of this kind exploit the government's "comparative advantage" in borrowing to smooth out income streams and facilitate risk sharing. By exploiting its position as the "natural borrower", or borrower of first resort, governments can minimize the extent to which disposable income, current cash flow and the portfolio of liquid, marketable or realizeable assets become binding constraints on private consumption, investment, production and portfolio allocation decisions.

This view of financial policy is at the opposite end of the spectrum from the ancient "debt neutrality" position as restated by Barro [1974] (see also Buiter [1979, 1980a] and Carmichael [1982]). Debt neutrality, i.e. invariance of the real solution trajectaries of the economy underchanges in the borrowing-taxation mix, prevails if financial policy cannot affect the intertemporal (including the intergenerational) distribution of income and terms of trade. With infinite-lived households or, equivalently, finite-lived households characterized by an operative chain of intergenerational gift and bequest motives, with private access to

2. e.g. Webb [1981] shows how government financial policy will be nonneutral in a world with asymmetric information, if it is less costly for the government to extract taxes from reluctant taxpayers than it is for private lenders to compel performance by dishonest borrowers. 
capital markets on the same terms as the government and with unrestricted lump-sum taxes and transfers, public sector financial policy is irrelevant. Relaxing any or all of these exceedingly restrictive assumptions causes this Modigliani-Miller theorem for the public sector to break down and a potential welfare-improving role for active financial policy to emerge.

Active financial policy is most easily defined as the orthogonal complement of passive financial policy. Passive financial policy I define as balanced budget financial policy, i.e. a continuous or periodby-period matching of receipts and expenditures. Weakly passive financial policy permits balanced budget redistribution; strictly passive financial policy compels taxes and taxes net of transfers and subsidies to be the same. It is well-known that, e.g. in the over-lapping generations model of Diamond [1965], a balanced budget social security scheme implemented through lump sum taxes on the young and lump-sum transfer payments to the old will depress capital formation. Most balanced budget intertemporal or intergenerational redistribution schemes can be reproduced in terms of their effects on all real endogenous variables by unbalanced budget policies involving public sector borrowing or lending. e.g. the social security scheme just mentioned is isomorphic to government borrowing with debt service financed by new debt issues and by lump sum taxes on the young. Without risk of ambituity I shall therefore identify active financial policies with policies that permit, under specified conditions, systematic and predictable departures from budget balance.

Active financial policy, as just defined, has a wide range of functions 
and. consequences, only a few of which can be considered here. By influencing the interpersonal, intertemporal and intergenerational distribution of income it will affect risk sharing, the extent to which households can smooth consumption over the life cycle and capital. formation. All this can occur in models in which current goods and labour markets clear continuously. I shall discuss this briefly in Section II. If lump sum taxes are not feasible, the timing of distortionary taxes will influence to total excess burden or dead weight loss imposed on the economy. The same will hold if tax collection costs in any given period are a more than linearly increasing function of the marginal or average tax rate in that period. This is considered in section III. Again this applies in labour and output market clearing models.

For models with a strong new classical flavour, it has been established that various contingent or conditional financial rules (monetary or fiscal feedback rules) which are, in general, inconsistent with continuous budget balance, will alter the joint distribution function of real economic variables by changing the information content of currently observed prices when there is incomplete information about the current state (Weiss [1980], Turnovsky [1980], Buiter [1980b, 1981]). While of some theoretical interest, this financial stabilization channel appears to be of secondary practical importance and I shall not consider it any further here.

In a world with persistent labour market and/or output market disequilibrium, the capital market imperfections that are the sine qua non of financial policy spill over into the markets for output and labour. E.g. the existence of the multiplier, which is due to the inclusion of current 
disposable income as an argument in the private consumption function, over and above its contribution to permanent income, reflects a capital market imperfection - the difficulty of borrowing against the security of anticipated future labour income. In a fixed price model the operation of the multiplier amplifies the effect of demand shocks on output and employment. Financial policy entailing temporary deficits may be the appropriate government response. $3 /$ The balanced budget multiplier theorem would appear to suggest that any desired response to demand shocks can be achieved without deficits by varying both exhaustive public spending and taxes net of transfers. I would argue that, to a first order approximation, optimal budgetary stabilization policy of this kind would involve varying taxes and transfers in response to demand shocks while leaving the path of public consumption and investment spending unchanged. The intuitive reasons for this are that if public sector consumption spending is worthwhile, it is worthwhile regardless of the aggregate demand shocks that afflict the economy and that the time profile of public sector capital formation is dictated within rather narrow limits by the time profile of future planned public sector production. The government's spending programme on goods and services should be designed to achieve the best feasible public-private consumption mix out of permanent national income. The tax-transfer-borrowing and money creation rules should be aimed at optimizing national permanent income, keeping private disposabie income in line with private permanent income and ensuring an adequate share of disposable, realizable (financial)

3. First best policy would eliminate the market imperfections. The discussion assumes that this has been pursued as far as is possible. 
private wealth in total or comprehensive private wealth, which includes such illiquid assets as human capital.

The above applies to the optimal design of exhaustive spending policies and financing policies. If, as in the U.K. today, certain categories of public spending (especially public sector capital formation) have been cut to levels that are well below most reasonable notions of optimality and if at the same time a "Keynesian" fiscal boost to aggregate demand is desirable, both structural (or allocative) and stabilization purposes can be served by a larger volume of spending on goods and services (social overhead capital formation and investment in some of the nationalized industries in the U.K.). In Section IV I review briefly some of the well-known arguments about the role of deficits and debt in short run stabilization policy when there is disequilibrium in labour and product markets.

Concern about debt and deficits on the part of the authorities tends to derive from two alleged consequences of public sector deficits. First, to the extent that deficits are monetized they are feared to lead to inflation. Second, to the extent that they are not monetized but financed by issuing interest-bearing debt, they are feared to "crowd out" interestsensitive private spending, especially private capital formation. This "crowding out" can occur either through upward pressure on real interest rates caused by additional borrowing or by displacing private capital formation at given real interest rates, as in sargent and wallace [1981] (see also Buitex [1982a, b; 1983]). Section V considers in some depth the 
"eventual monetization" implied by the government's fiscal and financial plans and the long-term financial crowding out ${ }^{4 /}$ implications of the government's budgetary and monetary policy. While these issues belong to the domain of positive rather than normative fiscal and financial policy, they are of considerable practical interest. On the principle that feasibility is a prerequisite for optimality section $V$ therefore analyses the sustainability, consistency and credibility of fiscal, financial and monetary policy. The comprehensive net worth and permanent income of the public sector are two central concepts in this analysis.

II. Financial policy with lump-sum taxes and transfers when goods markets and factor markets clear.

Using the analytical framework of the simple overlapping generations model without intergenerational gift and bequest motives, Stiglitz [1983a,b] establishes the following propositions for the case where unrestricted lump sum taxes and transfers are possible and output and factor markets clear.

Proposition I (Stiglitz 1983a)

An increase in the government deficit has neither real nor inflationary effects so long as the associated changes in (lump sum) taxes are distribution

4. I only consider the familiar financial crowding out issue. Other forms of "direct" crowding out due to complementarity or substitutability between private and public consumption and investment etc. are not dealt with (see Buiter [1977]). 
neutral and so long as the debt will eventually be reduced to its original level.

Proposition II (Stiglitz 1983b)

A temporary change in the structure (maturity composition, nature and degree of index linking, etc.) of the public debt has no real or price level effects provided it is accompanied with the appropriate lump sum taxes/subsidies to avoid any distributive effects.

Proposition III (Stiglitz 1983a, b)

A change in the interest rate paid on (unindexed) government debt financed by a change in the supply of such debt has price level effects but no real effects.

Note that all these propositions apply to an economy in which there is no explicit or implicit transactions technology. Government debt has a store of value function only; there is no special medium of exchange or means of payment function for a subset of the public sector's financial liabilities, i.e. there are no monetary assets. "Inflation" in Stiglitz's models is a decline in the price of public debt in terms of real output. The first two propositions give the conditions under which the ModiglianiMiller theorem for the public sector holds in this economy. The third proposition is the familiar classical dichotomy. 
The interest of Propositions I - III lies in the extreme restrictiveness of the conditions under which financial policy will be neutral. Stiglitz goes on to show that

Proposition IV (Stiglitz 1983a)

Any anticipated changes in financial policy other than those described in propositions I, II and III have both real and price level effects on the economy. Any unanticipated change has no real effects on the economy only if it doesn't change individual's subjective probability distributions concerning future government financial policy and if all changes in debt are accompanied by changes in lump-sum taxes and subsidies to neutralize any distributional consequences.

Having established the non-neutrality of "almost all" financial policy actions or rules, the design of optimal financial policy can be tackled. Since the class of models under consideration is rather far removed from practical applications, I shall limit the discussion to two aspects of optimal financial policy.

Government debt and private capital formation

In the Diamond version of the overlapping generations model, debt issues involve redistribution from the young to the old. This depresses saving and capital formation in the short run and lowers the steadystate capital-labour ratio. In such economies private decentralized decision making can result in equilibria in which the real interest rate 
is below the natural growth rate. This dynamic inefficiency can be eliminated by issuing government debt to absorb excessive private saving. If the real interest rate exceeds the growth rate such paretoimproving financial policies are not feasible. Given the government's social welfare function (which would typically be strictly increasing in the welfare of each generation), social welfare improving financial policy actions may still exist. E.g. budget surpluses and government lending can boost capital formation. The welfare loss this imposes on those currently old may be more than compensated for by the welfare gains of the young and of future generations.

Optimal intertemporal risk distribution schemes

The effects of financial policy on private capital formation occur even without uncertainty. In a stochastic environment government financial policy can generate changes in the intertemporal (and specifically the intergenerational) distribution of risk. In the two period overlapping generations model, individuals of different generation cannot trade risks in the market place. The longevity of the institution of government permits intergenerational risk sharing through the public debt-tax-transfer mechanism. A detailed analysis can be found in Stiglitz (1983a, b) who shows that the optimal (in terms of an individualistic social welfare function ${ }^{5 /}$, intertemporal distribution of wealth and risk can be implemented, at a constant price level, through financial policy involving only a single

5. Stiglitz [1983a] uses a social welfare function that is the discounted sum of each generation's utility. The proposition about optimal intergenerational risk sharing transcends this specific parameterization. 
financial instrument provided the government can impose age-differentiated lump-sum taxes and transfers. When lump-sum taxes and transfers cannot be fully adapted to individual characteristics, the existence of a variety of public sector debt instruments is potentially welfare improving.

The time profile of debt and deficits under optimal financial policy will be a function of all taste and technology parameters in the economy, of the stochastic shocks disturbing it and of the authorities' objective functional. Generalizations are impossible other than the rather selfevident one that a policy of continuous budget balance is likely to be . optimal under a set of conditions of measure zero.

III. Financial policy with distortionary taxes and transfers when goods markets and factor markets clear.

Recently Barrow [1979, 1981] and Kydland and Prescott [1980] have applied a well known "uniform taxation" theorem in public finance to the macroeconomic problem of optimal public sector debt and deficits in an economy with continuous full employment. In the absence of uncertainty and given suitable symmetry, homogeneity and separability assumptions, it is optimal to levy wage taxes at a constant proportional rate throughout an individual's lifetime. (See Sandmo [1974, 1976], Sadka [1977] and Atkinson and stiglitz [1980]). The argument assumes the non-availability of lump sum taxes and subsidies. The original public finance literature was formulated in terms of the deadweight loss or excess burden of fiscal 
programs involving distortionary taxes, whose minimization (under fairly strict conditions) required the equalization of planned tax rates over the present and the future. Barro's papers consider the possibility of tax collection costs being an increasing and strictly convex function of the ratio of the net total tax take to the tax base. Even in nonstochastic models, a rigorous statement has not been given of the conditions under which the result holds true that the optimal total tax take as a proportion of GDP (or of labour income?) is constant over time, for an economy with the real-world plethora of direct and indirect taxes, taxes on labour and capital income and taxes on wealth. For a stochastic environment, Barro [1981] has argued that the deterministic constant planned tax rate solution translates approximately into a Martingale process for the tax rate $\tau$, i.e.

$$
E\left(\tau_{t+i} \mid \Omega_{t}\right)=\tau_{t} \quad i \geq 0
$$

$E$ is the conditional expectation operator and $\Omega_{t}$ the information set conditioning expectations formed at time $t$ lassumed to include $\left.\tau_{t}\right)$.

Equation (1) follows from its deterministic counterpart only by abuse of certainty equivalence. For (1) to be strictly correct, a LQG (linearquadratic-gaussian) model structure is required. Given quadratic deadweight losses, linear constraints and additive white noise disturbances,

6. A non-fatal flaw in his analysis is the absence of collection costs in the government budget constraint and the independence of the tax base from collection costs and the time path of taxes. (See Kremers [1983]). 
equation (1) follows. An important (and implausible) restriction this imposes is that of non-stochastic discount rates.

Many empirical as well as conceptual problems stand in the way of a direct application of (1) to normative or positive policy design. How does one approximate the "average marginal tax rate" that belongs in equation (1)? What is the proper tax base to relate the tax rate to? Should one use taxes or taxes net of transfers and subsidies, as the theory suggests?

In spite of these and other objections to the strict "uniform expected tax rates over time" proposition, the notion that it is optimal to smooth planned tax rates relative to planned exhaustive public spending because collection costs and/or excess burdens increase more than linearly with the tax rate, is likely to be robust. $\frac{8 /}{\text { In }}$ the strict version of equation (1) the theory implies that a temporary increase in public spending unaccompanied by a matching increase in real output (the tax base) should be financed at least in part by borrowing. A transitory increase in real output will, given public spending, be associated with a budget surplus. The "countercyclical" behaviour of the deficit that will characterize the economy if the exogenous level of output follows a regular cyclical pattern and public spending is constant has nothing to do with Keynesian fiscal stabilization

7. The same assumptions have to be made to obtain the Martingale property for the stochastic process governing consumption. See Hali [1978].

8. See pp 17 and 18 .

9. This can be taken relative to trend output. 


\section{Footnote 8}

The crucial constraint in the derivation of the uniform intertemporal pattern of tax rates in Barro [1979] is the government's balance sheet constraint.

(i) $\sum_{i=1}^{\infty} \frac{G_{t+i \mid t}}{(1+r)^{i}}+b_{t}=\sum_{i=1}^{\infty} \frac{T_{t+i \mid t}}{(1+r)^{i}}$

$G_{t+i \mid t}$ is exhaustive public spending planned, at time $t$, for time $t+i$. $T_{t+i \mid t}$ is taxes net of transfers planned at time $t$ for time $t+i$. For simplicity the real interest rate, $x$, is assumed constant. $b_{t}$ is the total stock of real valued single-period bonds in period $t$. Equation (i) follows from the budget constraint given in (ii) only if the real interest rate exceeds the real growth rate of the tax base.

(ii) $G_{t}+r b_{t-1}=T_{t}+b_{t}-b_{t-1}$.

From (ii) it follows that

(iiia) $\sum_{i=1}^{\infty} \frac{G_{t+i \mid t}}{(1+r)^{i}}+b_{t}=\sum_{i=1}^{\infty} \frac{T_{t+i} \mid t}{(1+r)^{i}}+\lim _{N \rightarrow \infty}\left(\frac{b_{t+N} \mid t}{(1+r)^{N}}\right)$

or

(iiib) $\sum_{i=1}^{\infty} \frac{G_{t+i} \mid t}{Y_{t+i \mid t}}\left(\frac{1+n}{1+r}\right)^{i}+\frac{b_{t}}{Y_{t}}=\sum_{i=1}^{\infty} \frac{T_{t+i \mid t}}{Y_{t+i \mid t}}\left(\frac{1+n}{1+r}\right)^{i}+\lim _{N \rightarrow \infty}\left\{\left(\frac{I+n}{1+r}\right)^{N} \frac{b_{t+N} \mid t}{Y_{t+N} \mid t}\right\}$

$Y_{t}$ is real output and $n$ its proportional rate of growth.

Sensible solutions require that the debt-output ratio remains bounded 
forever. This would cause the last term on the right-hand side of (iii $a, b)$ to vanish if $n<r$. If $n>r$, however, Ponzi games can work forever. Governments can forever service their debt by further borrowing without any risk of debt service requirements outstripping the government's collateral. A competitive, decentralized overlapping generations economy can have temporary and stationary solutions with $\mathrm{n}>\mathrm{r}$. Indeed, Carmichael [1982] and Buiter [1980] show that if there are intergenerational gift and bequest motives and if there is a stationary equilibrium in which the child-to-parent gift motive is operative, then such an equilibrium is necessarily dynamically inefficient with $n>r$. Like Barro, I make use of a government wealth constraint such as (i) in section $V$. This means that unless $n<r$, the "no Ponzi game" restriction is imposed in an ad-hoc manner. 
policy or the operation of the automatic stabilizers, however. These are considered in the next section.

IV. Optimal debt and deficits when labour and output markets don't clear

The Keynesian arguments for running larger deficits (smaller surpluses) when effective demand is depressed and smaller deficits (larger surpluses) when effective demand is buoyant are familiar. Tax cuts in the face of negative demand shocks (or the "automatic" decline of taxes and rise in transfer payments when economic activity falls, that is written into most existing tax and benefit laws) help maintain disposable income. To the extent that disposable income rather than permanent income is the binding constraint on private demand, such active financial policy helps dampen fluctuations in output and employment.

In Keynesian models, with workers off their notional labour supply schedules and possibly also firms off their notional demand curves for labour, avoiding demand-induced swings in real activity is sensible policy.

By reducing taxes (net of transfers) and increasing borrowing during the downswing, exhaustive public spending during the downswing will be financed to a larger extent by private agents who are not constrained by current disposable income - the purchasers of the bonds. Total consumption demand will therefore decline by less than if taxes, which I assume to fall equally on disposable-income-constrained and permanent income-constrained 
private agents, had been kept constant during the downswing. When the economy recovers, the additional debt incurred during the downswing can be repaid out of higher than normal taxes. The demand effects of cyclical tax cuts during the downswing and tax increases during the upswing may not be symmetric if, as seems likely, more private agents are constrained in their spending by current disposable income during the downswing than during the upswing.

The smoothing out of consumption over the cycle permitted by countercyclical financial policy would be desirable because of its intertemporal allocative effects even if product and factor markets cleared. Its virtues are enhanced by the initial demand-disturbance-amplifying presence of labour and output market disequilibrium.

When used for cyclical stabilization, successful financial policy should not imply any trend increase in the real stock of debt or in the debt-output ratio. If real interest rates are increasing functions of current and anticipated future deficits, the transitory and reversible deficits that are associated with countercyclical policy should have but minor effects on real interest rates. Thus, by raising the level of activity, countercyclical deficits absorb private saving in the short run without lowering the capital stock in the long run. If real interest rate determination is more myopic, even short run and reversible increases in deficits and debt may lead to significant crowding out of interestsensitive private spending. In most existing macromodels such crowding out can be avoided by monetizing part of the deficit. Provided this 
monetization is reversed (and is expected to be reversed) in proper countercyclical fashion during the upswing, it should have no effect on trend monetary growth and thus on inflationary expectations.

For the sake of completeness, I will conclude this section with the familiar reminder that there are no "model-free" measures of the shortrun effect of fiscal or financial policy on aggregate demand. Neither the uncorrected or raw deficit, nor the cyclically corrected deficit, nor the cyclically and inflation-corrected deficit nor the permanent deficit of Section $V$ are proper measures of fiscal impact. The "demandweighted" (i.e. marginal-propensity-to-spend-on-domestic-output-adjusted), cyclically corrected deficit calculated e.g. in the U.K. by the National Institute of Economic and Social Research, as well as the "demandweighted", cyclically adjusted and inflation corrected deficit calculated for the U.K. by Buiter and Miller [1983] are appropriate indices of the short-run demand effect of fiscal policy only in a static, rather oldKeynesian and expectations-innocent model. $\stackrel{10 /}{ }$ The first best approach would be to simulate one's preferred model of the economy under different values of fiscal and financial policy parameters and to call the difference between the solution trajectories (or the statistics describing them) the measure of fiscal impact. These fiscal stance measures will therefore a) be model-specific, b) have time subscripts attached to them and c) be functions of when a particular fiscal or financial action (or rule change) was first anticipated, of its anticipated degree of permanence and of the degree of confidence with which these expectations are held.

10. In the case of Buiter and Miller [1983] the "inflation correction", or more appropriately, the debt service correction, presupposes that private financial intermediaries transform current interest payments from governments into permanent (disposable) real interest income flows to households. 
V. Longer-run aspects of the fiscal and monetary stance: sustainability, consistency and credibility

Preoccupation with the current budget deficit or public sector borrowing requirement (PSBR) can be criticized for a variety of reasons. First, the budget deficit is likely to be a poor or even perverse indicator of the short-run cyclical demand effects of spending and taxation policy. Second the size or change of the deficit bears no straightforward relation to the allocative or structural effects of government spending and tax programmes. A third major reason for not paying too much attention to the PSBR is that it conveys little or no information on the sustainability of the fiscal stance, i.e. on the consistency of long-term budgetary spendingtaxation plans, monetary targets and financial crowding out objectives. The level or change in the current deficit are uninformative as to the credibility of the government's budgetary, debt and monetary policy.

In what follows I combine the comprehensive accounting framework developed in Buiter [1983] with the permanent cost of debt service approach of Miller (Miller [1982], Miller and Babbs [1983]). With this apparatus one can address the following issues. First, can previously planned spending programmes be financed, given projected real output growth, without raising explicit tax rates or increasing seigniorage (the inflation tax)? Second, what is the "eventual monetization" implied by the fiscal stance, i.e. is the government's anti-inflationary monetary stance fiscally compatible and credible? Third, given the 
spending and taxation plans and the monetary target, is there likely to be financial "crowding in" our "crowding out", i.e. is there a tendency for the real stock of interest bearing debt to fall or to rise (relative to trend output)?

To evaluate sustainability and consistency we complement the government budget constraint given in (2) by a comprehensive public sector balance sheet in (3):

$$
\begin{aligned}
& \text { (2) } g+\dot{K}-\tau+i \frac{B}{p}+\frac{C}{p}-i \star \frac{\varepsilon F^{*}}{p}-p_{K} K-\rho_{R} R+p_{R} \dot{R} \equiv \frac{\dot{M}+\dot{B}+p_{C} \dot{C}-\varepsilon \dot{F^{*}}}{p} \equiv \text { P.S.B.R. } \\
& \text { (3) } W \equiv p_{K} K+p_{R} R+T+\Pi-\frac{\left(M+B+p_{C} C\right)}{p}+\frac{\varepsilon F^{*}}{p}
\end{aligned}
$$

$\mathrm{g}$ is public sector consumption spending; $\mathrm{K}$ the public sector capital stock; $\tau$ taxes net of transfers, $i$ the short nominal interest rate; $B$ the stock of short nominal bonds; $p$ the general price level; $C$ the number of consols paying 1 \$ each period; $i$ * the foreign nominal interest rate; $F^{*}$ the net foreign currency denominated assets of the public sector; $\varepsilon$ the foreign exchange rate; $\rho_{K}$ the rental on public sector capital; $\rho_{R}$ the return to a unit of publicly owned natural resource rights; $R$ the stock of publicly owned natural resource property rights; $P_{R}$ the price of $R ; M$ the nominal stock of high-powered money; $\mathrm{p}_{\mathrm{c}}$ the money price of a consol; $\mathrm{w}$ real public sector net worth; $p_{K}$ the value of a unit of public sector capital in the public sector; $T$ the present discounted value of future expected taxes net of transfers $\tau$; $\pi$ the real capital value of the state's note issue monopoly and $r$ the short real rate of interest. Public sector net worth is made up 
of tangible real assets, $K$ and $R$, financial liabilities $M, B, C$ and $-F^{*}$ and intangible assets $T$ and $\Pi$. The capital value of the note issue monopoly II is found by discounting the future income derived from the assets that are held to "back" the note circulation.

The public sector capital stock is valued not at replacement cost but as the present value of its future returns on the assumption that it remains in the public sector. The value of a publicly owned unit of capital $\left(p_{K}\right)$ need therefore not be the same as its value in alternative (private) use or replacement cost which is set equal to 1 . (See equation (2).) Indeed $\mathrm{p}_{\mathrm{K}}$ could be negative. Without loss of generality the total (public + private) stock of natural resource property rights is treated as constant. $\dot{R} \geqslant 0$ therefore means public sector acquisitions (sales) of natural resource rights. Oil discoveries as well as changes in the price of oil, are represented by changes in $\mathrm{P}_{\mathrm{R}}$. For simplicity expected rates of return on all assets are assumed to be equalized. This heroic use of certainty equivalence is a serious limitation of the current presentation of the comprehensive wealth and permanent income approach. Index-linked bonds (short and/or long) could be added to the framework without complications. For expositional simplicity the entire maturity distribution of the public debt is represented by the shortest and longest maturities.

The PSBR in Britain is measured by the right-hand side of (2). Sales of existing public sector assets (natural resource rights and public sector capital) are put "above the line" and cet. par. reduce the PSBR where they involve the ending of majority public ownership. The public sector financial 
Footnote 11,

We therefore assume that:

$$
\begin{aligned}
& p_{K}(t)=\int_{t}^{\infty} \rho_{K}(s, t) e^{-\int_{t}^{s} r(u, s) d u} d s \\
& P_{R}(t)=\int_{t}^{\infty} \rho_{R}(s, t) e^{-\int_{t}^{s} r(u, s) d u} d s \\
& T(t)=\int_{t}^{\infty} \tau(s, t) e^{-\int_{t}^{s} r(u, s) d u} d s \\
& \Pi(t)=\frac{1}{p(t)} \int_{t}^{\infty} i(s, t) M(s, t) e^{-\int^{s} i(u, t) d u} d s \\
& =\int_{t}^{\infty} r(s, t) \frac{M(s, t)}{p(s, t)} e^{-\int_{t}^{s} r(u, t) d u} d s \\
& p_{C}(t)=\int_{t}^{\infty} e^{-\int^{s} i(u, s) d u} d s . \\
& i *(t)=i(t)-\varepsilon_{1}(t, t) \\
& r(t)=i(t)-p_{1}(t, t)
\end{aligned}
$$

For any variable $x, x(s, t)$ is the value of $x$ expected, at time $t$, to prevail at time s. $x_{1}(t, t) \equiv \lim _{\substack{h \rightarrow 0 \\ h>0}}\left(\frac{(x(t+h, t)-x(t, t)}{h}\right)$ is the expected instantaneous rate of change of $x$.

$x_{2}(t, t) \equiv \lim _{\substack{h \rightarrow 0 \\ h>0}}\left(\frac{x(t+h, t+h)-x(t+h, t)}{h}\right)$ is the unexpected rate of change of $x$. It is assumed that $x(s, t)=x(s)$ for $s \leq t$. Given some minor regularity conditions it then follows that $\dot{x}(t)=x_{1}(t, t)+x_{2}(t, t)$. 
deficit on a national accounts basis places all sales of existing assets "below the line", with conventional borrowing and money creation.

The rate of change of public sector net worth $\dot{W}(t)$ can be decomposed into an anticipated part, $w_{1}(t, t)$, and an unanticipated part $W_{2}(t, t)$. It is easily checked that the anticipated change in $w$ is given by :

(4)

$$
\begin{aligned}
W_{I}(t, t)=r(t) W(t)+\left(P_{K}(t)\right. & -1) \dot{K}(t)-g(t) \\
=-\{g(t)-r(t)(T(t)+S(t)) & -r(t)\left(p_{K}(t) K(t)+p_{R}(t) R(t)+\frac{\varepsilon(t) F^{*}(t)}{p(t)}\right. \\
& \left.\left.-\frac{\left(B(t)+p_{C}(t) C(t)\right)}{p(t)}\right)-\left(p_{K}(t)-1\right) \dot{K}(t)\right\}
\end{aligned}
$$

where the present value of future seigniorage $S(t)$ is given by

$$
S(t) \equiv \int_{t}^{\infty} \frac{M_{1}(s, t)}{M(s, t)} \frac{M(s, t)}{p(s, t)} e^{-\int^{s} r(u, t) d u} d s .
$$

For ex ante or planning purposes only the expected change in $w(t)$ is relevant and we shall focus on this.

12. Unanticipated changes in $W$ are due to unexpected changes in $P_{K^{\prime}} P_{R^{\prime}} T, \Pi$, $P_{C^{\prime}} \varepsilon$ and $p$. E.G. the unexpected change in $T$ is given by

$$
\mathrm{T}_{2}(t, t)=\int_{t}^{\infty} e^{-\int^{s} r(u, t) d u}\left[\tau_{2}(s, t)-\tau(s, t) \int_{t}^{s} r_{2}(u, t) d u\right] d s .
$$

The present value of future taxes net of transfers increases if there is an unexpected increase in future values of $\tau$ and if there is an unexpected reduction in future discount rates (if $\tau(s, t)>0$ ). 
When $\mathrm{p}_{\mathrm{K}}=1$, public sector net worth decreases if and only if there is a "real" deficit, i.e. if public sector consumption expenditure exceeds the instantaneous (short run) real return on comprehensive public sector net worth, $r(t) W(t)$. Public sector capital formation does not affect public sector net worth if the shadow price of capital in the public sector, $\mathrm{P}_{\mathrm{K}}$, equals its opportunity cost, 1 , but will raise (reduce) net worth if $\mathrm{p}_{\mathrm{K}}>1 \quad(<1)$.

One characterisation of a sustainable fiscal plan requires public sector net worth to grow at the natural rate of growth of output, $n, i . e$.

$$
\begin{aligned}
& \text { (6) } \mathrm{w}_{\mathcal{I}}(t, t)=\mathrm{n} w \\
& \text { or } \\
& \text { (6!) } g(t)=\bar{r}(t) w(t)+\left(p_{K}(t)-1\right) \dot{K} \\
& \text { where } \bar{r}=r-n . \\
& \text { and } \mathrm{n}=\bar{y} / \bar{y}
\end{aligned}
$$

If $g(t)$ were to exceed (fall short) of the right-hand side of $\left(6^{\prime}\right)$, public sector comprehensive net worth would be falling (rising) ex ante relative to trend GNP. If $p_{K} K, p_{R} R, T, S$ and $\frac{\varepsilon F^{\star}}{p}$ all grew at the natural rate, the entire decline (increase) in the public sector net worth-GNP ratio would come about through an increase (reduction) in the interest-bearing debt-GNP ratio. In most models not exhibiting debt neutrality, such an increase (decrease) in the "debt burden" causes financial crowding out (crowding in). The degree and time pattern of this financial crowding out (in) will of course be model specific. A simple model with full crowding out is given in 
Sargent and Wallace [1981] (see also Buiter [1982(a,b), 1983].

Even if $p_{K}(t)=1$, a programme satisfying (6') which would keep the expected public sector net worth-trend GDP ratio constant, implies anticipated variations in the share of public consumption in trend net output, if the short real interest rate varies over time. An alternative and more desirable approach, following Hicksian permanent income notions, starts from the constraint (assumed to hold with strict equality) that the present value of public consumption must not exceed $W(t)$, i.e.

$$
G(t)=W(t) \equiv p_{K} K+p_{R}^{R}+T+S-\left(\frac{B+p_{C} C}{p}\right)+\frac{\varepsilon F^{\star}}{p}
$$

where

$$
G(t) \equiv \int_{t}^{\infty} g(s, t) e^{-\int^{s} r(u, t) d u} d s .
$$

Given the value of tangible assets and liabilities, $\mathrm{p}_{\mathrm{K}} \mathrm{K}+\mathrm{p}_{\mathrm{R}} \mathrm{R}-\left(\frac{\mathrm{B}+\mathrm{p}_{\mathrm{C}} \mathrm{C}}{\mathrm{p}}\right)+\frac{\varepsilon F^{\star}}{\mathrm{p}}$, an increase in the public consumption spending programme requires an increase in the present value of future explicit taxes-net-of-transfers $(T)$ and/or in the present value of future seigniorage, $S$. An increase in $S$ is commonly assumed to require an increase in the (average) future rate of monetary growth and thus in the rate of inflation.

$$
13 /
$$

13. This will not be so if the inflation elasticity of the demand for real high-powered money is negative and greater than unity in absolute value. 
Other ways of raising public sector net worth discontinuously, at a point in time, to finance a costlier public consumption programme are by improving the productivity of public sector capital (an increase in $\mathrm{p}_{\mathrm{K}}$ ) or, if $\mathrm{p}_{\mathrm{K}}<1$, by a sale of public sector capital (at its replacement value) to the private sector, using the proceeds to reduce $\frac{{ }^{B}+P_{C} C}{p}$, say. Finally, default is an option, either de jure, by formally repudiating debt, or de facto, by engineering an upward jump in the price level (which is a possibility in most New Classical models), a downward jump in the price of long-dated bonds or, if $F^{\star}>0$, a real depreciation of the currency.

Note that there are certain to be mechanisms at work in the economy that link the various items in (7) together. E.g. in a Keynesian world, a cut in the spending programme $(G(t))$ may lower the tax base and thus $T(t)$ even at given tax rates. If the economy exhibits financial crowding out (the displacement of private capital by public sector interest-bearing debt) a larger value of $\frac{B(t)+p_{C}(t) C(t)}{p(t)}$ might reduce $T(t)$, etc.

We can rewrite (8) as

$$
\int_{t}^{\infty} \cdot \frac{g(s, t)}{\bar{y}(s, t)} e^{-\int[r(u, t)-n] d u} d s=\frac{w(t)}{\bar{y}(t)}
$$

The constant, indefinitely sustainable, share of public sector consumption in trend GNP, $\left[\frac{g}{\bar{y}}\right]^{p}$, is given by 


$$
\left[\frac{g(t)}{\bar{y}(t)}\right]^{p}=\bar{R}(t) \frac{W(t)}{\bar{y}(t)}
$$

where

$$
\bar{R}(t)=\left[\int_{t}^{\infty} e^{-\int^{-s}[r(u, t)-n] d u} d s\right]^{-1}
$$

$\bar{R}(t)$ is the coupon yield on a real consol, when the instantaneous real rate of return is $r(t)-n$ and the strict expectations hypothesis holds, i.e. investors equate anticipated real rates of return.

Thus a share of public sector consumption in trend GDP in excess of $\left(\frac{g(t)}{\bar{y}(t)}\right)^{F}$ is unsustainable: it would lower permanent income. One way in which this unsustainability could show up would be through a steady rise in the real cost of narrowly defined debt service $\bar{R}\left(\frac{p_{C} C+B}{p}\right)$, i.e. through increasing financial crowding out pressure. Two useful indicators of the (un) sustainability of the current fiscal stance are therefore the excess of current consumption over the value consistent with a constant ratio of net worth to trend output or "constant net worth deficit"

$$
D^{W}(t) \equiv g(t)-\bar{r}(t) W(t)+\left(1-p_{K}(t)\right) \dot{K}(t)
$$

and the excess of current consumption over "permanent income" (that value of consumption consistent with a permanently constant share of public consumption in trend output) or "permanent deficit".

14. This is by abuse of language, since this deficit can by construction not be permanent. 
(11b)

$$
D^{P}(t) \equiv g(t)-\bar{R}(t) W(t)
$$

The two indices coincide when the real rate of return is expected to be constant $(\bar{r}(t)=\bar{R}(t))$ and the public sector uses its capital with the same degree of inefficiency as the private sector $\left(p_{K}=1\right)$.

The direct approach to evaluating $D^{W}$ or $D^{P}$ is, from $(11 a, b)$, by the construction of an empirical proxy for $W$. For $D^{W}(t)$ we multiply this by the short real rate interest net of the natural rate of growth; for $D^{\mathrm{P}}(t)$ the real consol coupon yield net of the natural rate of growth must be estimated. Even more informative would be a complete calculation of both sides of (7). As this involves projecting the entire course of future public consumption spending, it is also more difficult in practice. Recent government pronouncements in the U.K. about the need for medium and long-term cuts in spending programmes to stop the tax burden from rising, can be evaluated using this framework, however.

At this stage, a piecemeal approach to the calculation of $D^{\mathrm{P}}$ and $\mathrm{D}^{\mathrm{W}}$, involving a series of "corrections" to the conventionally measured PSBR seems convenient. The various corrections required to go from the PSBR to the permanent and constant net worth deficits are summarised in equations (12a, b). 
(12a) $D_{D}^{p}(t) \doteq \operatorname{PSBR}(t)-p_{R}(t) \dot{R}(t)-\dot{K}(t)+[\bar{R}(t)-i(t)] \frac{B(t)}{p(t)}$

$$
\begin{aligned}
& +\left[\bar{R}(t)-\frac{1}{p_{C}(t)}\right] \frac{p_{C}(t) C(t)}{p(t)}-(\bar{R}(t)-i *(t)) \frac{\varepsilon(t) F^{*}(t)}{p(t)} \\
& -\left(\bar{R}(t)-\frac{\rho_{K}(t)}{p_{K}(t)}\right) p_{K}(t) K(t) \\
& -\left(\bar{R}(t)-\frac{\rho_{R}(t)}{p_{R}(t)}\right) p_{R}(t) R(t)-(\bar{R}(t) T(t)-T(t))-\bar{R}(t) S(t) .
\end{aligned}
$$

$$
\begin{aligned}
& D^{W}(t)=\operatorname{PSBR}(t)-p_{R}(t) \dot{R}(t)-p_{K} \dot{K}-\left(\frac{p_{1}(t, t)}{p(t)}+n\right) \frac{B(t)}{p(t)} \\
& +\left(\bar{r}(t)-\frac{1}{p_{C}(t)}\right) \frac{p_{C}(t) C(t)}{p(t)}+\left(n+\frac{p_{1}(t, t)}{p(t)}-\frac{\varepsilon_{1}(t, t)}{\varepsilon(t)}\right) \frac{\varepsilon(t) F^{\star}(t)}{p(t)} \\
& -\left(\bar{r}(t)-\frac{p_{K}(t)}{p_{K}(t)}\right) p_{K}(t) K(t) \\
& -\left(\bar{r}(t)-\frac{p_{R}(t)}{p_{R}(t)}\right) p_{R}(t) R(t)-(\bar{r}(t) T(t)-\tau(t))-\bar{r}(t) S(t) .
\end{aligned}
$$

Since $D^{p}(t)$ is probably the more interesting of the two measures, we shall concentrate on it. Taking the corrections to the PSBR in (12a) in turn:

- $p_{R} \dot{R}(t)$ : This is a proxy for those net sales of existing public sector assets that should be added to the PSBR to get the public sector financial deficit (PSFD) on a national accounts basis.

$-\dot{K} \quad: g(t)$ in $(12 a, b)$ is public sector consumption spending. Many categories of exhaustive public spending possess characteristics both of 
consumption and capital formation. In the illustrative figures for the U.K. given in Table 1 I finesse these problems by following standard national income accounting conventions. On this basis, estimates of public sector net capital formation (at replacement cost) which should be subtracted from the PSBR and PSFD as one of the steps to get to $D^{P}$, are available in the U.K.

$+(\bar{R}-i) \frac{B}{p}+\left(\bar{R}-\frac{1}{p_{C}}\right) \frac{p_{C} C}{p}$ : this is not merely an inflation and real growth correction but also involves the permanent income smoothing reflected in the use of the long real interest rate. ${ }^{15 /}$ (This last step is omitted in (12b).) In public sector permanent income, debt service on the bond debt should be evaluated by multiplying the real long run (consol) rate of interest net of the natural growth rate, $\bar{R}(t)$, into the market value of all bonds. Estimates for this correction for the U.K. and a discussion of its methodological foundations are given in Miller [1982] and in Miller and Babbs [1983]. They are reproduced here in Table I.

- $\left(\bar{R}-i^{*}\right) \frac{\varepsilon F^{*}}{p}$ : This corrects for changes in the domestic currency value of foreign currency denominated assets and liabilities as well as for domestic inflation, real growth and permanent income smoothing. It is very important for a number of LDC's which have borrowed externally in dollars or other hard currencies. (See Buiter [1983].) Its significance for the U.K. and U.S. is likely to be quite minor.

15. For conventional inflation corrections see Siegel [1979], Threadgold and Taylor [1979] and Cukierman and Mortensen [1983]. 
- $\left(\bar{R}-\frac{P_{K}}{P_{K}}\right) ' p_{K} K$ : It is difficult to assess the size and magnitude of the excess of current income from public capital over permanent income and I do not attempt to do so. It is likely to be strongly procyclical.

- $\left(\bar{R}-\frac{P_{R}}{P_{R}}\right) P_{R} R: \quad$ North sea oil revenues are currently at or near their expected peak value. While in the mid and late seventies current oil revenue fell short of its permanent value (as perceived at the time) this situation is now reversed. The figures in Table 1 are merely illustrative but are quite conservative, in the sense that they are more likely to understate permanent oil revenue.

- $(\bar{R} T-\tau): \quad$ It should be clear that current taxes net of transfers $\tau(t)$ is likely to be a poor proxy for $\bar{R}(t) T(t)$. The most important "corrections" to $\tau(t)$ required to obtain a better approximation to $\bar{R}(t) T(t)$ are the following:

(a) "Cyclical" corrections to tax receipts and transfer payments. The yield from several major taxes (income taxes, national insurance contributions, VAT, corporation tax) varies inversely with cyclical deviations of economic activity from its full employment, trend or natural level. The opposite correlation holds for such transfer payments as unemployment benefits. Cyclical corrections to the conventionally measured deficit are, from this perspective, desirable not because they provide a better approximation to the short-run demand effect of the budget, but as one step towards the calculation of public sector permanent income or of the permanent deficit. 
In Table 1 I use the IMF's estimates of the cyclical correction. These are very conservative in that they do not assign a zero cyclical correction to 1979 but instead assume the cyclically corrected deficit to be $2.3 \%$ of GDP larger than the actual deficit in 1979 and $1.4 \%$ of GDP in 1980.

This seems to indicate an expectation of a normal unemployment rate in the U.K. of 8 or 9 per cent. The Institute of Fiscal studies, $\stackrel{17 /}{ }$ on the other hand, while coming up with very similar year-to-year changes in the cyclical correction, puts its level 2 to $2 \frac{1}{2}$ percentage points of GDP higher. What matters for the sustainability calculation is that a reasonable proxy for the expected average future levels of capacity utilization and unemployment be used. These levels may well be functions of the fiscal policies adopted by the authorities and need not be equal to any "natural" or "full employment" values.

(b) There may be planned, projected or expected changes in the scale and scope of certain tax and benefit programmes. E.g. under existing legislation governing contributions and benefits, the greying of the U.K. population implies a growing excess of pension payments over contributions. Similar concerns have been voiced in the U.S. While one could try to make some further rough structural or demographic corrections to the "cyclically corrected" tax and transfer total, I have not done so in Table I.

16. IMF World Economic outlook.

17. John Kay [1983] 
- $\overline{R S}:$ The perpetuity value of future seigniorage revenue is not so easily determined. Following the definition of $s(t)$ given in (7), one must estimate future government plans for monetary base growth $\frac{\dot{i}}{M}$ and future demands for real high-powered money balances $\frac{M}{p}$.

Note that

$$
\bar{R}(t) \frac{S(t)}{\bar{Y}(t)}=\bar{R}(t) \int_{t}^{\infty} \frac{M_{1}(s, t)}{M(s, t)} \frac{M(S, t)}{P(s, t) \bar{Y}(s, t)} e^{-\int_{t}^{S}[r(u, t)-n] d u} d s .
$$

If both the rate of monetary growth and the income velocity of circulation of money are expected to be constant, then

$$
\bar{R}(t) S(t)=\frac{\dot{M}(t)}{P(t)} \ldots \text { permanent seigniorage income relative }
$$

to trend output equals its current value. I will make this assumption, but the overall outcome is not very dependent on it as the amounts involved are fairly small. 


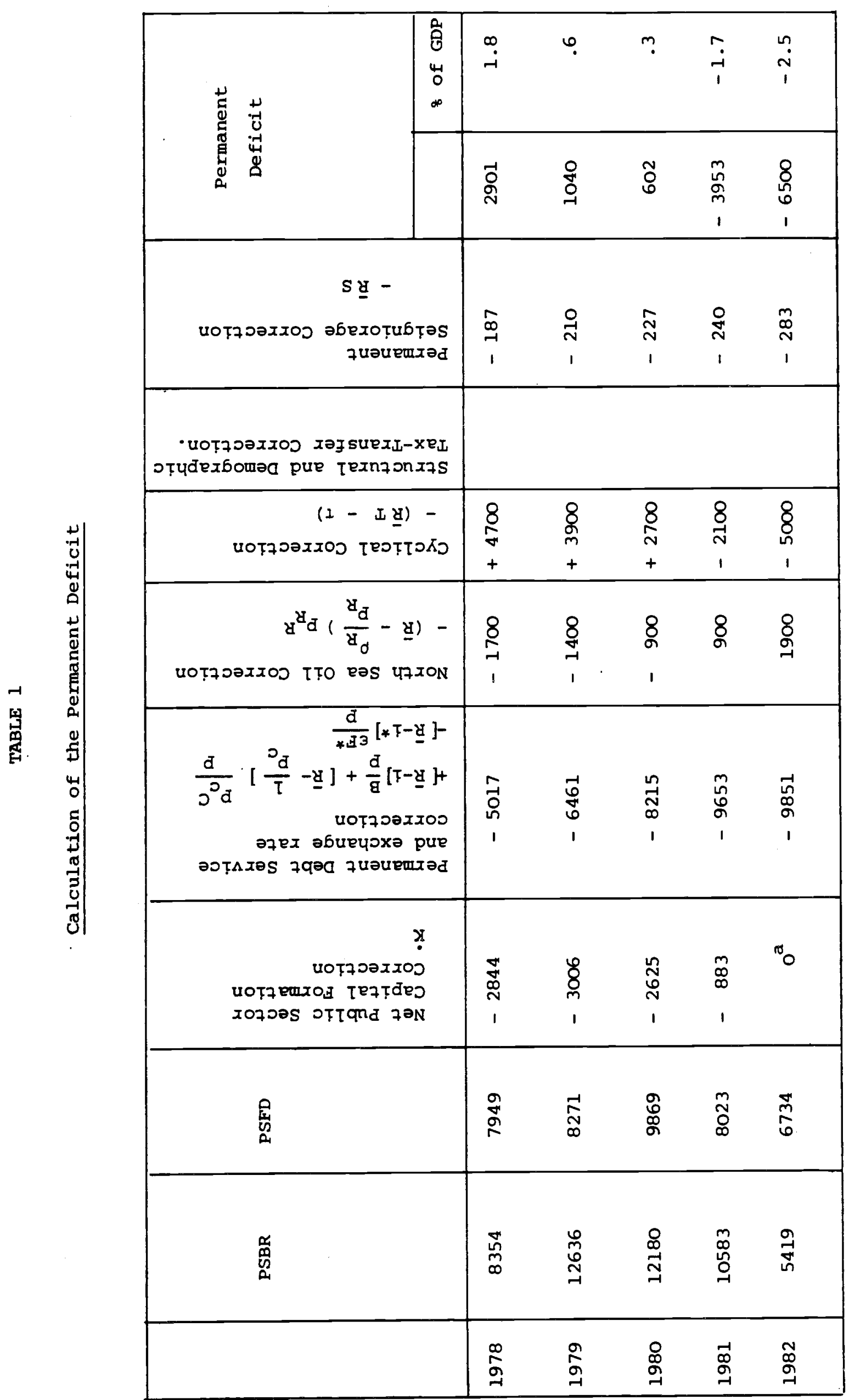


SOURCES:

- PSBR, PSFD : ET May 1983, 56

- $\dot{\mathrm{K}} \quad$ : $\quad$ Blue Book 1982 ed. 1.7 for 1978-1981. 1982 own estimate.

- Permanent Debt Service Correction: Miller and Babbs [1983].

- North Sea Oil Correction: Own calculations based on NIER, May 1983. F.J. Atkinson, S.J. Brook and S.G.F. Hall, "The Economic Effects of North Sea Oil", pp 38-44; IFS, John Kay ed., The Economy and the 1983 Budget; M.P. Devereux, "Changes in the Taxation of North Sea Oil", pp. 75-79.

- Cyclical Correction: IMF World Economic Outlook, 1982, Table 49, p.187.

- Permanent Seigniorage Correction: Monetary base x long-run real rate; Source: Miller \& Babbs [1983] 
Adopting the IFS cyclical correction instead of the one calculated by the IMF would lower the permanent deficit by 2 to $2 \frac{1}{2}$ per cent of GDP compared to the figures in the last column of Figure II. Together with a slightly more generous estimate of the permanent income from North Sea oil this would generate a 5 or 6 per cent of GDP permanent surplus in 1982. This would leave room for a sizeable sustainable increase in the share of public consumption spending in trend GDP over its current level and/or a cut in taxes or increase in transfer payments. Alternatively the government could choose to indulge in a bout of financial "crowding in", using its "permanent" surplus to reduce the real stock of interestbearing debt. The U.K. economy, unlike the USA, would appear to have lots of fiscal elbow room.

\section{Eventual Monetization}

The apparatus developed here can be applied to the calculation of the "long-run" monetary growth rate implied by the fiscal stance.

From (5) and (7) it follows that

$$
\begin{aligned}
& \int_{t}^{\infty} \frac{M_{1}(s, t)}{M(s, t)} \frac{M(s, t)}{P(s, t)} e^{-\int_{t}^{S} r(u, t) d u} d s=G(t) \\
& -\left[P_{K}(t) K(t)+P_{R}(t) R(t)+T(t)-\frac{\left(B(t)+P_{C}(t) C(t)-\varepsilon(t) F^{*}(t)\right)}{P(t)}\right] .
\end{aligned}
$$


This tells us what the amount of revenue to be raised through the inflation tax is (in present value terms) given the spending programme and the government's tangible and intangible non-monetary assets and liabilities. Solving this for a constant rate of monetary growth $\frac{\dot{M}}{M}$ and a constant income velocity of circulation $v \equiv \frac{p \bar{y}}{M} \quad y i e l d s$

$$
\begin{array}{r}
\frac{\dot{M}}{M}=V \bar{R}(t)\left[\frac{G(t)-T(t)}{\bar{y}(t)}-\left(\frac{p_{K}(t) K(t)+p_{R}(t) R(t)}{\bar{y}(t)}\right)\right. \\
\left.+\frac{B(t)+p_{C}(t) C(t)-\varepsilon(t) F^{*}(t)}{p(t) \bar{y}(t)}\right]
\end{array}
$$

If the long-run inflation rate is governed by the rate of growth of the money supply, say $\frac{\dot{p}}{p}=\frac{\dot{M}}{M}-n$, and if the inflation elasticity of velocity is less than unity, a higher monetary growth rate and a higher rate of inflation are implied by a higher present value of public spending relative to non-monetary assets and liabilities. Only if the publ1c sector's consumption and tax programmes, together with its nonmonetary assets and liabilities, imply a high value of $\frac{\dot{M}}{M}$ is a fiscal correction a necessary condition for achieving credibility for an anti-inflationary policy. If we consider only.stationary long-run equilibria, (13) becomes

$$
\frac{\dot{M}}{M}=V\left[\frac{g-\tau}{\bar{Y}}-\bar{R}\left(\frac{p_{K}^{K}+p_{R}^{R}}{\bar{y}}\right)-\frac{\left(B+p_{C} C-\varepsilon F^{*}\right)}{p \bar{Y}}\right]
$$

Eventual monetary growth is governed in steady state by the trend public sector current account (or consumption account) deficit, with debt service evaluated at the real interest rate net of the natural rate of growth. 
This deficit measure can differ dramatically from the conventionally measured public sector financial deficit or PSBR, which is often and erroneously taken as an indicator to eventual monetization. (See sargent [1981], Sargent and Wallace [ 1981] and Buiter [ 1982a,b] and Buiter [ 1983].)

VI Conclusion

Bringing together in an integrated analytical framework the many heterogeneous perspectives on debt and deficits that were touched upon in this paper is left as an exercise for the reader. What is apparent even now is that the theory of macroeconomic policy design, as it relates to public spending, taxation, debt management, social security, and monetary and exchange rate policy, is a branch of the theory of public finance, albeit a rather underdeveloped branch. Most traditional public finance theory has been restricted to the case of walrasian, market-clearing economies with a complete set of markets. Most macroeconomic analysis, except for some simple supply-side economics, ignores the efficiency aspects of fiscal and financial policy. The arbitrary and indeed very harmful dichotomy between "macroeconomic" stabilization policy - using fiscal and financial instruments to minimize deviations from full employment equilibrium - and "public finance" allocative or structural policy - altering the full employment equilibrium - can no longer be justified.

Both the "classical" and the "Keynesian" approaches to financial policy reviewed in this paper force one to conclude that a balanced budget policy is very likely to be harmful in a wide range of circumstances. 
While mere sound economic analysis is unlikely to convince those who are firmly committed to a balanced budget, it may help persuade a sufficient number of uncommitted citizens of the need to ban this spectre of false fiscal responsibility. 


\section{REFERENCES}

A B Atkinson and J.E. Stiglitz [1980], Lectures on Public Economics, New York, McGraw-Hill.

Robert J Barro [1974], "Are Government Bonds Net Wealth?", Journal of Political Economy, 82, pp 1095-1117.

Robert J Barro [1979] "On the Determination of the Public Debt", Journal of Political Economy, 87, October 1979, pp 940-71.

Robert J. Barro [1981], "On the Predictability of Tax Rate Changes", NBER Working Paper No 636, February 1981.

Willem H Buiter [1977], "Crowding Out and the Effectiveness of Fiscal Policy", Journal of Public Economics, 7,

Willem B Buiter [1979], "Government Finance in an Overlapping Generations Model with Gifts and Bequests" in G. van Furstenberg, ed. Social

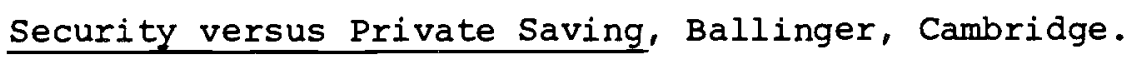

Willem H Buiter [1980a], "'Crowding out' of Private Capital Formation by Government Borrowing in the Presence of Intergenerational Gifts and Bequests", Greek Economic Review, 2, August 1980, pp 111-142.

Willem B Buiter [1980b], "Monetary, Financial and Fiscal Policy Under Rational Expectations" IMF Staff Papers, 27, Dec. Pp. 758-813. 
Willem H Buiter [1981], "The Superiority of Contingent Rules over Fixed Rules in Models with Rational Expectations", Economic Journal, 91, September, pp 647-670.

Willem H Buiter [1982a], "Comment on T J Sargent and N. Wallace: Some Unpleasant Monetarist Arithmetic", NBER Working Paper No 867, March.

Willem H Buiter [1982b], "Deficits, Crowding Out and Inflation: The Simple Analytics", Centre for Labour Economics, London School of Economics, Discussion Paper No. 143, December.

Willem H Buiter [1983], "The Measurement of Public Sector Deficits and its Implications for Policy Evaluation and Design" " IMF Staff Papers, June 1983.

Willem H Buiter and Marcus H Miller [1983], "The Economic Consequences of Mrs Thatcher", Unpublished, August.

J. Carmichael [1982], "On Barro's Theorem of Debt Neutrality: The Irrelevance of Net Wealth", American Economic Review, 72, March, pp 202-213.

Alex Cukierman and Jorgen Mortensen [1983], "Monetary assets and inflation-induced distortions of the national accounts - conceptual issues and the correction of sector income flows in 5 EEC countries", Commission of the European Communities, Directorate General for Economic and Financial Affairs, Economic Papers, No 15, June. 
P A Diamond [ 1965], "National Debt in a Neoclassical growth model" American Economic Review, 55, December, pp 1125-1158.

R.E. Hall [1978], "Stochastic Implications of the Life Cycle-Permanent Income Hypothesis: Theory and Evidence", Journal of Political Economy, 86, December, pp 971-987.

John Kay [1983] ed., The Economy and the 1983 Budget, Basil Blackwell, 1983, p. 45 .

Jeroen J M Kremers [1983] "Public Debt Neutrality, Tax Collection Costs, and Optimal Public Financing", Nuffield College, University of Oxford, Unpublished, April.

Finn Kydland and Edward C Prescott [1980], "A Competitive Theory of Fluctuations and the Feasibility and Desirability of Stabilization Policy" in Stanly Fischer, ed. Rational Expectations and Economic Policy, pp 169-187, University of Chicago Press.

Marcus H Miller [1982], "Inflation-Adjusting the Public Sector Financial Deficit", in J. Kay, ed. The 1982 Budget, oxford.

Marcus H Miller and Simon Babbs [1983], "The True Cost of Debt Service and the Public Sector Financial Deficit", mimeo, April 1983.

E. Sadka [1977], "A Theorem on Uniform Taxation", Journal of Public Economics, 7, June 1977, pp 387-391. 
A. Sandmo [1974], "A Note on the Structure of Optimal Taxation", American Economic Review, 64, September, pp 701-706.

A. Sandmo [1974], "Optimal Taxation: An Introduction to the Literature", Journal of Public Economics, pp 37-54.

Thomas J Sargent [1981], "Stopping Moderate Inflations: The Methods of Poincaré and Thatcher", May, unpublished.

Thomas J Sargent and N. Wallace [1981], "Some Unpleasant Monetarist Arithmetic", unpublished, October.

J. Siegel [1979], "Inflation-Induced Distortions in Government and Private Saving Statistics", Review of Economics and Statistics, February 1979, pp 83-90.

Joseph E Stiglitz [1983a] "On the Relevance or Irrelevance of Public Financial Policy", NBER working Paper No 1057, January.

Joseph E Stiglitz [1983b] "On the relevance or irrelevance of public financial policy: Indexation, price rigidities and optimal monetary policy", NBER working Paper No 1106, April.

Joseph E Stiglitz and A Weiss [1981], "Credit Rationing in Markets with Imperfect Information", American Economic Review, 71, June, pp 393-410. 
Joseph E Stiglitz and A Weiss [1983], "Cutting off Credit: An Application of Constraints as Incentive Devices", American Ecenomic Review, forthcoming.

C T Taylor and A R Threadgold [1979], "'Real' National Saving and its Sectoral Composition", Bank of England, Discussion Paper No 6, October.

S J Turnovsky [1980], "The Choice of Monetary Instruments Under Alternative Forms of Price Expectations", Manchester School, March, pp 39-62.

David C Webb [1981], "The Net wealth Effect of Government Bonds when Credit Markets are Imperfect", Economic Journal, 91, June, pp 405-414.

I Weiss [1980], "The Role for Active Monetary Policy in a Rational Expectations Model", Journal of Political Economy, 88, April, pp 221-233. 